\title{
Salon
}

\section{John Snow, hero of cholera: RIP}

$\infty$

See related article on page $169 \mathrm{I}$

$\mathrm{D}$

r. John Snow is not the first man to be honoured for valorous acts he never accomplished, nor is he the first to have honest, partially successful work transformed into a miraculous success. On the 20oth anniversary of Snow's death it is time to acknowledge the glorious failure to accept that Snow's cholera studies were not good enough.

The problem is not Snow, but the mythology that has grown around him, the fable of the heroic researcher who single-handedly "proved" cholera was waterborne. He did not. Here is the myth broken down into its components.

Myth I: Snow developed the idea of inscribing individual cases in maps that would argue the nature, origin and source of a disease outbreak. In fact, the first "spot-map" of a disease outbreak arguing etiology was created by Valentine Seaman in 1798 in a study of a New York City outbreak of yellow fever. ${ }^{1}$ By the I8zos disease maps had become a common instrument of epidemiological study.

Myth 2: Snow single-handedly pioneered the "shoe-leather epidemiology" of local case studies. Again, Seaman's study, and other studies of yellow fever and cholera, used this type of case analysis.

Myth 3: Snow's data were individually generated. In fact, the case reports he investigated and mapped were derived from weekly mortality reports issued by the General Registrar Office in London, England. Most of his cases came from local physicians and the local parish curate, Rev. Henry Whitehead, who visited every family in the area of the Broad Street outbreak.

Myth 4: Snow's South London study was a success. It failed because Snow was unable to organize a street-level

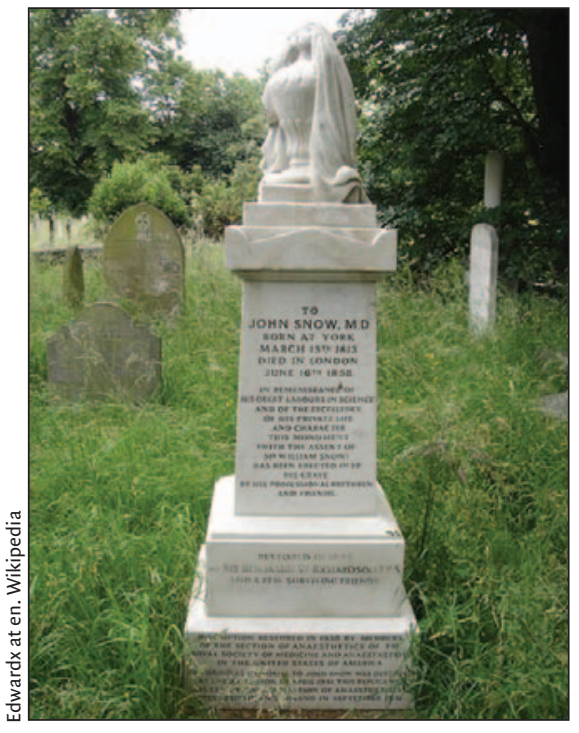

Snow, who was buried in London, England, embodies the myth of the brilliant solitary researcher.

study that would permit correlations between water supplier and cholera rates. It was Dr. John Simon who completed the study in $1856 .^{2}$ Snow used the same data in an innovative model whose structural problems were analyzed recently by modern researchers. ${ }^{3}$

Myth 5: Snow's contemporaries did not listen. Actually, his contemporaries did listen, but remained unconvinced because Snow left legitimate questions unanswered.

Myth 6: Snow's methodology was well performed. In fact, it was not. In the Broad Street study, for example, Snow did not include simple - and available - mortality ratios.

After his death Snow's work fell into general obscurity until resurrected by William Thompson Sedgwick as a teaching tool in his Igor "sanitary science" textbook. ${ }^{4}$ Others built on the story in the I930s and I950s. The limits of Snow's work were forgotten, its heroic brilliance exalted.
The myth of Snow is not a harmless fable. It ignores the fact that what we call John Snow's cholera studies were not the work of a lone individual; this denies the community of science while promoting the myth of the brilliant, solitary researcher.

Yes, cholera is waterborne but science is not about being "right." It is about convincing others of the rightness of an argument and that Snow did not do. Ignoring that does violence to the idea of juried research, and of the community of science that Snow passionately participated in.

Let John Snow rest in peace. Let the myth die, too. It is not a fable we need today.

\section{Tom Koch PhD}

Bioethicist

Vancouver, BC

\section{REFERENCES}

I. Seaman V. Inquiry into the cause of the prevalence of yellow fever in New York. Medical Repository I798;I:314-32.

2. Simon J. Report on the last two cholera-epidemics of London as affected by the consumption of impure water. London: George E. Eyre and William Spottiswoode printers; 1856 .

3. Koch T, Denike K. John Snow's South London study: a Bayesian evaluation and recalculation. Soc Sci Med 2006;63:27I-83.

4. Sedgwick WT. Principles of sanitary science and the public health with special reference to the causation and prevention of infectious disease. New York: The Macmillan Company; I902.

This article is excerpted from Tom Koch's lecture, "Cholera in I850s London: John Snow and his contemporaries," presented May 8, 2008 at the Warburg Institute, University of London. Tom Koch has written widely on Igth-century cholera and John Snow.

Have you got an opinion about this article? Post your views at www.cmaj.ca. Potential Salon contributors are welcome to send a query to salon@cma.ca. 